\title{
P-T conditions of cataclastic deformation associated with underplating: An example from the Cretaceous Shimanto complex, Kii Peninsula, SW Japan
}

\author{
Yoshitaka Hashimoto $^{1}$, Mamoru Enjoji ${ }^{2}$, Arito Sakaguchi ${ }^{3}$, and Gaku Kimura ${ }^{3,4}$ \\ ${ }^{1}$ Kochi University, Akebonocho 2-5-1, Kochi 780-8520, Japan \\ ${ }^{2}$ Waseda University, Nishiwaseda 1-6-1, Sinjuku-ku, Tokyo 169-8050, Japan \\ ${ }^{3}$ The Institute for Frontier Research of Earth Evolution, JAMSTEC, Yokosuka 237-0061, Japan \\ ${ }^{4}$ University of Tokyo, Hongo 7-3-1, Tokyo 113-0033, Japan
}

(Received January 11, 2002; Revised August 15, 2002; Accepted August 27, 2002)

\begin{abstract}
P-T conditions of cataclastic deformation associated with underplating in subduction zone are estimated from fluid inclusions within the post-mélange veins in the Cretaceous Shimanto Belt, Kii Peninsula, SW Japan. Both cataclasite and post-mélange veins cut the mélange fabric and are distributed along the thrusts in duplex structure. The homogenization temperatures range from $200( \pm 10)^{\circ} \mathrm{C}$ to $270( \pm 42)^{\circ} \mathrm{C}$ corresponding to entrapment pressures over a wide range from $145( \pm 5) \mathrm{MPa}$ to $304(-20) \mathrm{MPa}$. Our results have important implications in evaluating the relationship between underplating processes by duplexing and coseismic deformation in accretionary complexes.
\end{abstract}

\section{Introduction}

Seismogenic regions along subduction zones could be constrained from thermal profiles as proposed by Hyndman and Wang (1993), who suggested a temperature range from ca. $100^{\circ} \mathrm{C}$ to $150^{\circ} \mathrm{C}$ for up-dip limit and from ca. $350^{\circ} \mathrm{C}$ to $450^{\circ} \mathrm{C}$ for down-dip limit in such regions. Vitrinite reflectance (e.g., Underwood et al., 1989; Sakaguchi, 1996; Ohmori et al., 1997) and illite crystallinity (e.g., Awan and Kimura, 1996) studies revealed that "fossil accretionary complexes" were subjected to temperatures in the range of $100^{\circ} \mathrm{C}$ to $300^{\circ} \mathrm{C}$. These results indicate that fossil accretionary complexes were possibly formed at the shallow to middle portions of the seismogenic region within subduction zones.

Structural and seismic studies on accretionary complexes have well-documented their evolution history, which include: (1) tectonic mélange formation originated from shear along decollement (Kimura and Mukai, 1991; Ohnishi and Kimura, 1995; Hashimoto and Kimura 1999), (2) duplex underplating (Silver et al., 1985; Murata, 1991; Hashimoto and Kimura, 1999), and (3) out of sequence thrusting (Ohmori et al., 1997). One of the prominent deformation mechanisms of tectonic mélange formation could be pressure solution which is believed to correlate with creep motion on fault (Ohnishi et al., 2001). The latter two processes (2 and 3) are possibly related to coseismic deformation. Recently, pseudotachylites have been reported from the Shimanto accretionary complex (Sakaguchi and Ikesawa, 2000), which is considered to be a direct evidence for coseismic motion. However, the tectonic setting and timing of formation of the pseudotachylites are equivocal.

Copy right(C) The Society of Geomagnetism and Earth, Planetary and Space Sciences (SGEPSS); The Seismological Society of Japan; The Volcanological Society of Japan; The Geodetic Society of Japan; The Japanese Society for Planetary Sciences.
In this paper, we examine whether the underplating processes by duplexing (mechanism 2) is related to coseismic deformation in accretionary complex. The study area is the Cretaceous Shimanto Belt, Kii Peninsula, SW Japan where Hashimoto and Kimura (1999) reported duplex structures in detail. We report the deformation mechanism of duplex structure formed by underplating and discuss the possible temperature range from P-T estimation in fluid inclusions within vein minerals along thrusts in the duplex structure.

\section{Geological Setting}

The Shimanto Belt crops out in the Pacific side of Japan from Kanto region to Ryukyu arc (Fig. 1(A)). On the basis of age, the Belt is divided into two, the Cretaceous subbelt in the northern part and the Tertiary sub-belt is in the southern part. The study area is located in the western end of the Miyama Assemblage (the Cretaceous sub-belt) in Kii Peninsula (Fig. 1(B)). The Miyama Assemblage is characterized by abundant basalt and pelagic sediments and cherts which are good key beds to recognize the map scale geological structures.

Figure 2 represents a geological map of the study area. The main component of this area is tectonic mélange. Two types of mélange are identified. Type I mélange is composed of basalt or chert blocks surrounded by shale matrix. Type II mélange is composed of only sandstone blocks in shale matrix. mélange foliation strikes almost EW and dips steeply to the north. Basalts are pillow lava or hyalloclastite. Cherts are often observed with basalts. The basalt-chert units are less than a hundred meters in thickness and extend almost parallel to the strike of mélange foliation. The basalt-chert unit is partially replaced by the type I mélange. Thrusts cutting the basalt-chert units at the bottom converge in part, which represents a composite duplex structure in map scale (Hashimoto and Kimura, 1999). The timing of subduction of 


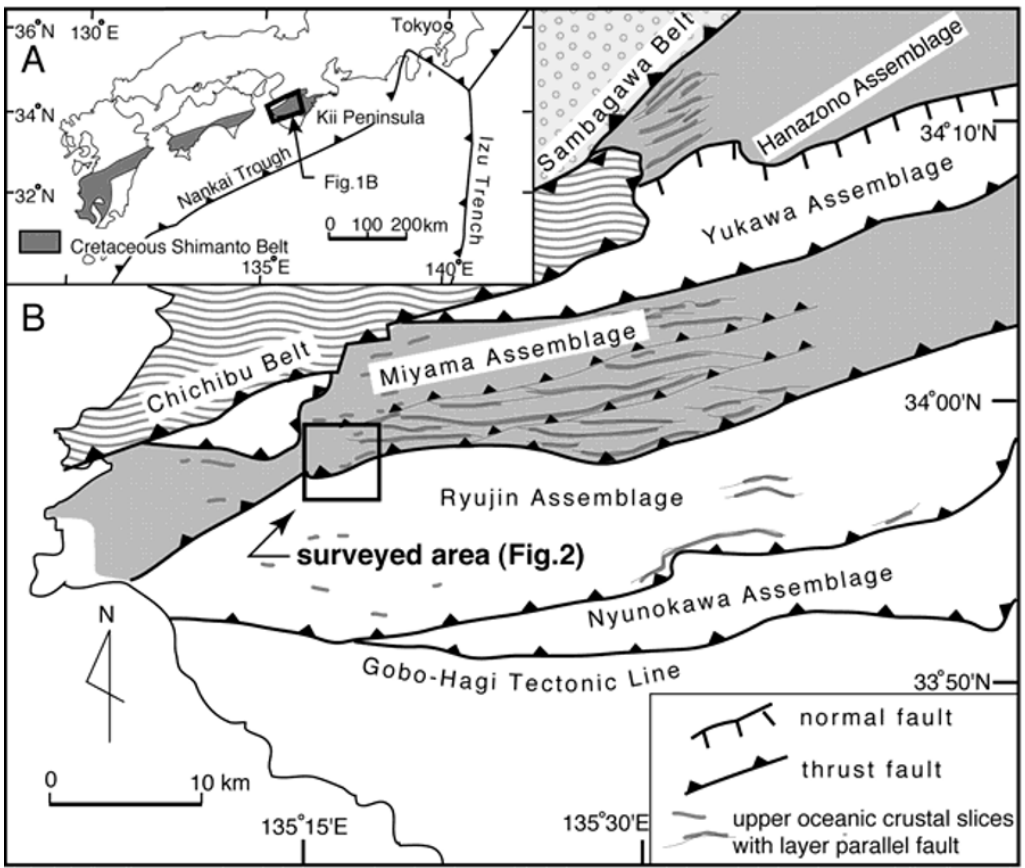

Fig. 1. A) Distribution of the Cretaceous Shimanto Belt in SW Japan. B) Geological outline of the Cretaceous Shimanto Belt, Kii Peninsula.

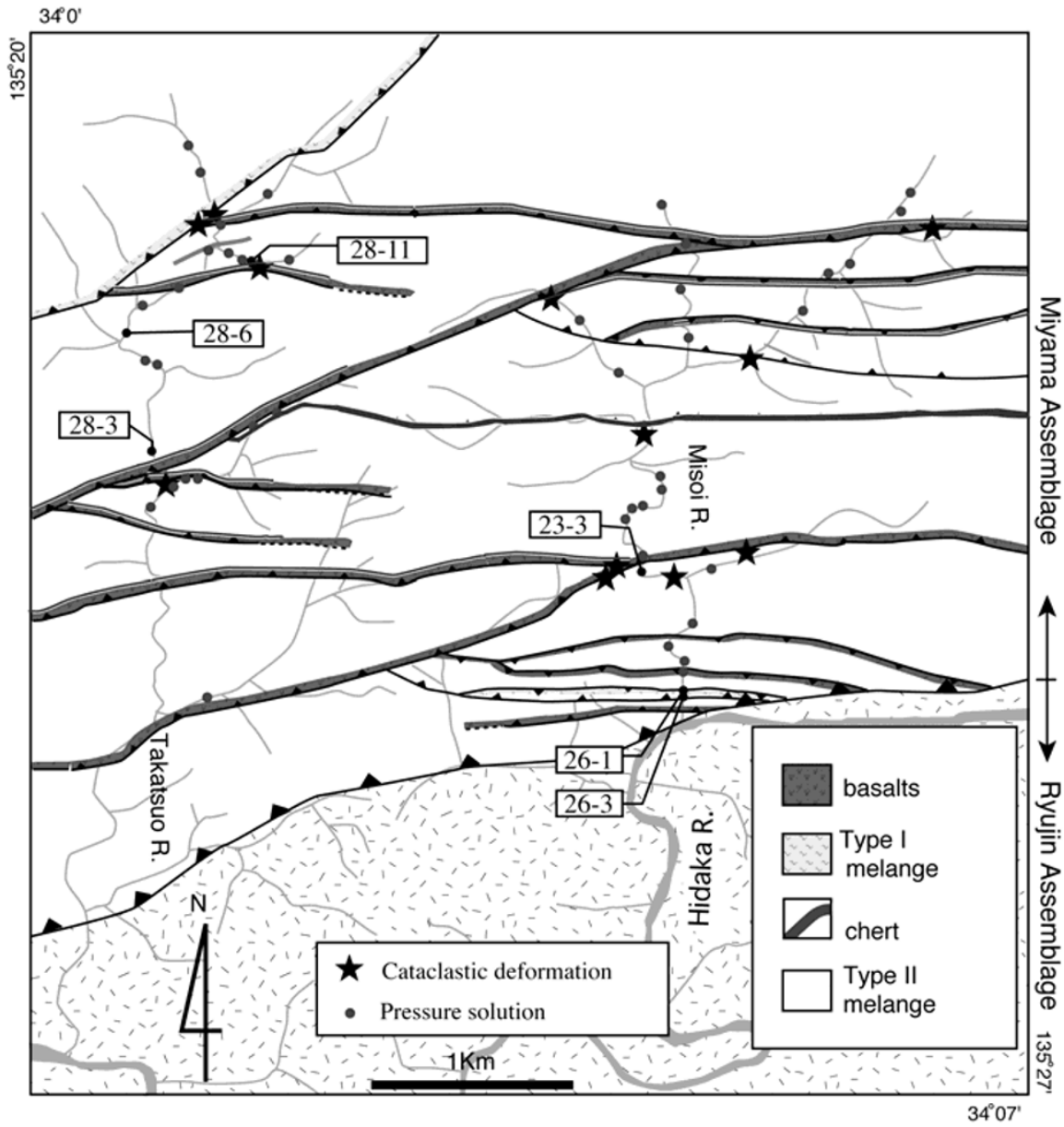

Fig. 2. Geological map of the study area. Location of map is shown in Fig. 1. Star indicates the location of cataclasis. Black dot shows the location of pressure solution. Box number represents the location of analyzed post-mélange vein. 
the oceanic plate is constrained by the age of the terrigenous shale matrix, which is given by the oldest pelagic sediments. Thus, the age of the oceanic plate at the time of subduction is estimated as follows; Valanginian (about from 132 to 135 Ma) minus Coniasian (about from 83 to $87 \mathrm{Ma}$ ) $=52$ to 45 million years. An estimate of ca. 50 m.y. is therefore used as the basis for heat flux calculation discussed below.

\section{Cataclastic Deformation along Duplex Struc- ture}

Cataclastic deformation is clearly identified on a microscopic scale. In outcrop scale, cataclastic textures are unclear because of strongly deformed mélanges. Brittle breakage of quartz grains in sandstone clasts in the type II mélange is represented in Fig. 3(A). The fragments flow along shear surfaces.

Distribution of cataclastic deformation and non-cataclastic deformation in map scale are shown in Fig. 2. All the cataclastic deformations locate near thrusts that constitute the duplex structure. Non-cataclastic deformation (mainly pressure solution) is the main deformation mechanism of mélange formation (Hashimoto and Kimura, 1999; Onishi et al., 2001). The locations of pressure solution distribute broadly within each thrust sheet (Fig. 2).

\section{Occurrence of Veins Related to Duplex Struc- ture}

Two types of veins are identified both in the outcrop and microscopic scales. The first category is syn-mélange veins that are developed only within the sandstone blocks. The syn-mélange veins are cut by shale matrix. Mud has been injected into the veins in some parts. The features associated with these occurrences suggest that a marked contrast in the competency of the layers existed between the sandstone and the mudstone at the time of development of the vein. Such contrast in competency may promote formation of boudinage or pinch and swell structure. We thus infer that these veins were formed at the same time of mélange formation. The second category is the post-mélange veins cutting mélange fabrics which were emplaced after mélange formation (Figs. 3(B) and (C)). These veins develop along brittle faults cutting mélange fabric (Fig. 3(C)). In this paper, we report the P-T estimation from the post-mélange veins. P-T estimation of the syn-mélange veins in the same study area is reported elsewhere (Hashimoto et al., submitted).

The main components of the post-mélange veins are quartz and/or calcite. The veins range in thickness from one $\mathrm{cm}$ to a few $\mathrm{cm}$. In microscopic scale, the quartz veins clearly cut both sandstone blocks and shale matrix, and do not diminish in the shale matrix (Fig. 3(B)).

Figure 2 shows the distribution of the post-mélange veins. Similar to the distribution of cataclastic deformation, the veins are distributed predominantly along thrusts constituting map-scale duplex structure. The overall distribution of the post-mélange veins is, however, limited. The veins in outcrop scale also tend to distribute along the thrusts. The relationship between cataclastic deformation and postmélange veins is discussed later.

\section{Occurrences of Fluid Inclusions}

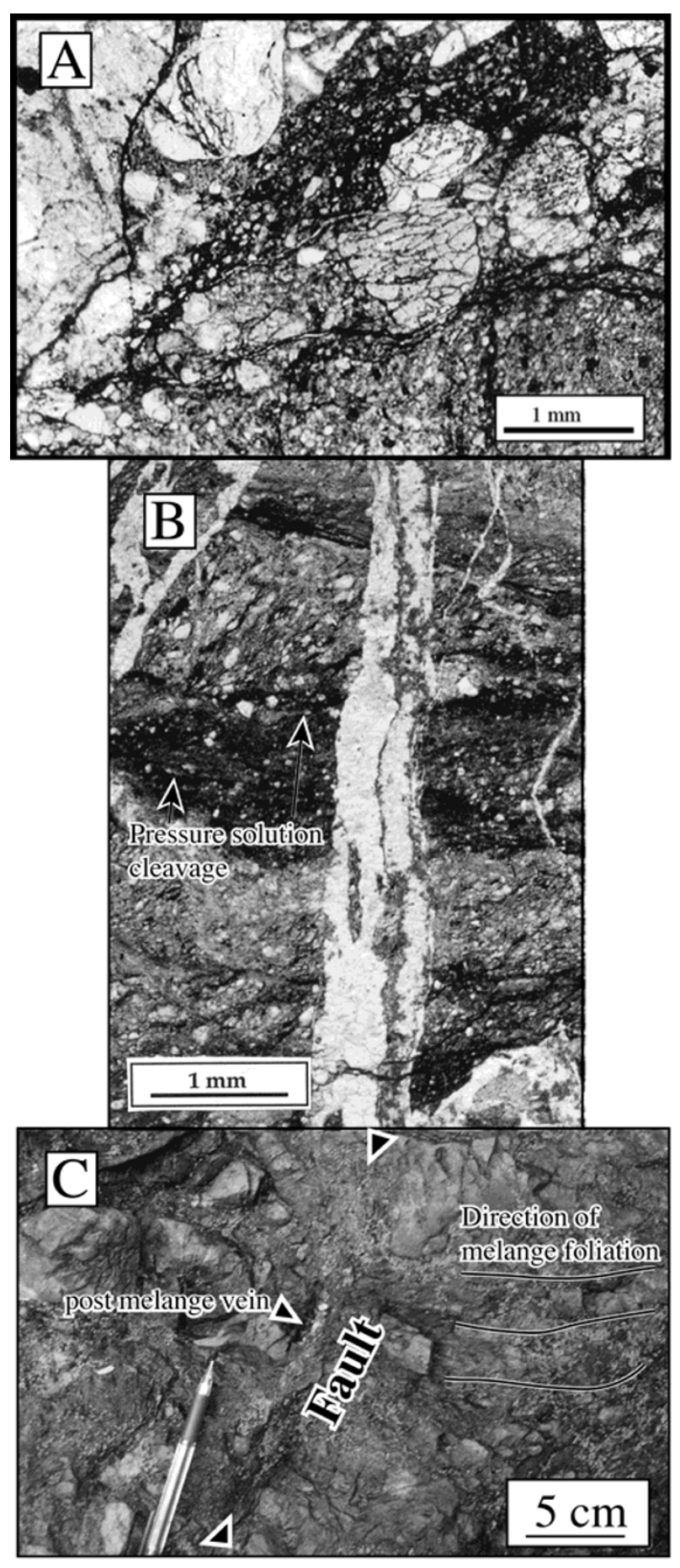

Fig. 3. A) Cataclasite deformation of sandstone. B) Post-mélange veins in microscopic scale cutting all the lithological boundaries between samdstone and mudstone and shear foliation of tectonic mélange. C) Post-mélange vein in outcrop scale along fault cutting mélange fabric.

Two types of fluid inclusions are recognized in the vein minerals. The first is inclusions that are monophase at room temperature and the other comprises inclusion that show two phases at room temperature.

A qualitative analysis of the composition of the fluid inclusions was performed using Fourier Transform Infrared Spectroscopy (FT-IR). FT-IR spectroscopy provides information on the molecular structure of the fluid within the inclusion. On the basis of FT-IR analysis, we identified that the one- 
Table 1. Result of fluid inclusion analysis.

\begin{tabular}{|c|c|c|c|c|c|c|}
\hline Sample No. & heating $(\mathrm{n})$ & cooling (n) & Trap temperature $\left({ }^{\circ} \mathrm{C}\right)$ & Cooling $\operatorname{Th}\left({ }^{\circ} \mathrm{C}\right)$ & Pressure (Mpa) & mineral \\
\hline $23 \_3$ & 8 & 26 & 220 & -120.5 & $223.1(+9.8 /-9.6)$ & $\mathrm{Qz}$ \\
\hline $26 \_1$ & 6 & 16 & 200 & -106.9 & $165.1(+3.6 /-3.4)$ & $\mathrm{Ca}$ \\
\hline $26 \_3$ & 9 & 7 & 200 & -120.5 & $212.6(+5.2 /-5.1)$ & $\mathrm{Ca}$ \\
\hline $28 \_11$ & 6 & 20 & 210 & -142.8 & $303.7(+19.5 /-0.0)$ & Qz \\
\hline $28 \_3$ & 4 & 25 & 230 & -104.1 & $168.2(+10.0 /-9.8)$ & Qz \\
\hline $28 \_6$ & 10 & 1 & 270 & -94.2 & $144.8(+5.1 /-5.5)$ & $\mathrm{Ca}$ \\
\hline
\end{tabular}

heating $(n)=$ number of inclusions analyzed from heating experiment, cooling $(n)=$ number of inclusions analyzed from cooling experiment, Cooling $\mathrm{Th}=$ homogenized temperature of cooling experiment, mineral = host mineral of the densest methane-rich inclusion, Qz $=$ Quartz, $\mathrm{Ca}=$ Calcite.

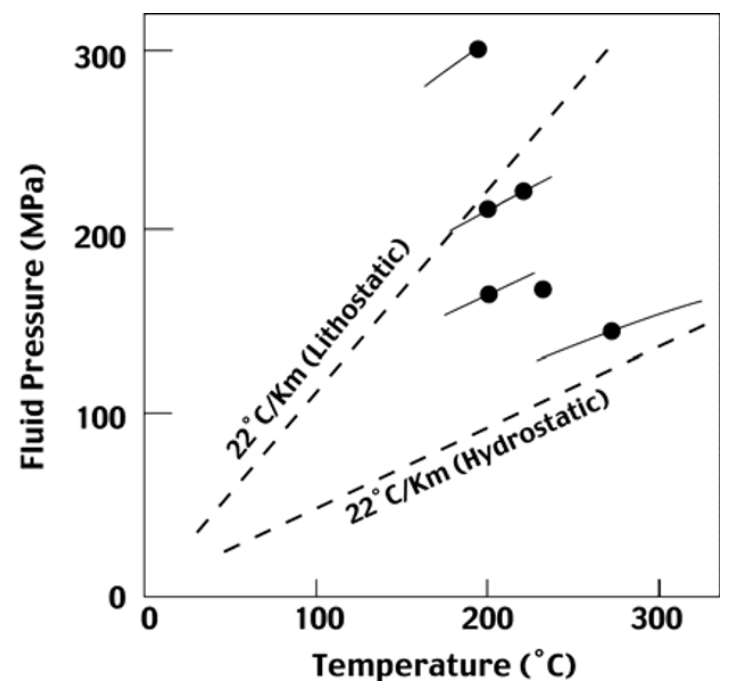

Fig. 4. Estimated P-T condition of post-mélange vein formation. Error bars indicate the variation of homogenized temperature of water-rich inclusions (trapping temperature). Because the modal value of trapping temperature is taken, the error bar is asymmetric. Broken lines indicate geothermal gradient estimated on the basis of subducting slab age for lithostatic and hydrostatic pressure, respectively.

phase inclusion is methane-rich, and the two-phase inclusion is water-rich. The result suggests that the $\mathrm{H}_{2} \mathrm{O}-\mathrm{CH}_{4}$ immiscible fluids might have coexisted at the time of trapping. This assumption further suggests that water methane-saturated aqueous fluids could have evolved a vapor-phase upon cooling due to decreasing solubility and umixing at lower temperatures, yielding two-phase inclusions of the type observed in these samples.

Primary inclusions in the investigated samples are characterized by rounded, irregular and prismatic cavities or negative crystal shapes (Roedder, 1984). They range in size from 20 to $50 \mu \mathrm{m}$ along the long axis. Primary inclusions are far less in number as compared to the common trails and planes of secondary inclusions. Inclusions showing necking-down features are also common. The secondary inclusions have small cavities with only few $\mu \mathrm{m}$ in diameter.

\section{Method and Result of Fluid Inclusion Analysis}

In this study, fluid inclusion analysis was conducted solely in primary inclusions in both quartz and calcite veins. Conventional microthermometric experiments were employed to estimate the trapping P-T conditions using a heating-freezing stage. The heating experiment was conducted on two-phase (water-rich) inclusions. The homogenization temperature obtained during heating experiments provides a direct estimation of the trapping temperature, because it coincides with the temperature of methane saturation of water at the time when the fluid was trapped.

Cooling experiments were performed on one-phase (methane-rich) inclusions. Methane bubbles appeared below $-83^{\circ} \mathrm{C}$ in this study. Although the inclusions were cooled down to $-170^{\circ} \mathrm{C}$, we did not observe the formation of solid carbon dioxide in any of them. We therefore infer that the amount of carbon dioxide in methane-rich inclusions, if at all present, is very small (Burruss, 1981), and that the effect of carbon dioxide in the homogenization of the methanerich inclusions in these samples is negligible. During reheating of the inclusions, the methane bubbles disappeared. The density of the $\mathrm{CH}_{4}$-phase is obtained from the homogenization temperature. In this study, we calculated P-T conditions from "the densest methane fluid inclusions" because the highest density among several fluid inclusions in a single crystal may indicate that the fluid was trapped under pressure conditions close to the lithostatic pressure. The isochore for $\mathrm{CH}_{4}$ was computed from the density values based on experimentally determined pressure-volume-temperature (P-V-T) properties of methane (Angus et al., 1976). The fluid pressure was obtained by combining the trapping temperature 
determined in the heating experiment and the isochore calculated during the cooling experiment. In one vein, quartz and calcite are intricately mixed. It was observed that the homogenization temperatures of inclusions during heating and cooling are not controlled by the type of host minerals. Six samples of the syn-mélange veins were analyzed in this study. In each vein, we measured about 15 homogenization temperatures for methane and 12 for $\mathrm{H}_{2} \mathrm{O}+\mathrm{CH}_{4}$ inclusions.

The melting temperature of these inclusions could not be analysed because of their small size which obscure clear documentation of the phase changes. During heating run, no decrepitation of inclusions was observed in any sample.

The results of P-T estimations are shown in Table 1 and Fig. 4. The trapping temperatures range from $200( \pm 10)^{\circ} \mathrm{C}$ to $270( \pm 42)^{\circ} \mathrm{C}$ and the obtained pressure represents a wide range from $145( \pm 5) \mathrm{MPa}$ to $304(-20) \mathrm{MPa}$.

\section{Discussion}

\subsection{Spacio-temporal relationship between cataclastic} deformation and the post-mélange vein formation

The spacio-temporal relationship between cataclastic deformation and the post-mélange veins formation is not totally resolved. The small number of post-mélange veins in outcrop scale for any detailed analyses of fluid inclusions, and the poor outcrop conditions inhibit direct observations and or conclusive remarks on the sequence of deformation and vein formation. However, it is possible to draw some general inferences.

Initially, trench-fill sediments were under unlithified condition with $50 \%$ to $60 \%$ porosity. Through underthrusting within subduction zones, the sediments became lithified due to dewatering, cementation and clay mineral transition. Hashimoto and Kimura (1999) suggest that underplating preceded mélange formation because mélange fabric is cut by duplex faults in map scale. Both cataclastic deformation along duplex faults and the post-mélange veins cut mélange fabric in brittle manner. Therefore, both of the cataclastic deformation and the post-mélange vein formation are events that post-date mélange formation and lithification. In addition, the accordance in distribution of the two processes may suggest that the post-mélange vein cutting mélange fabrics with brittle faults were associated with the cataclasitic deformation along the duplex faults.

\subsection{P-T condition of fluid after mélange formation}

Estimated P-T conditions of the post-mélange veins do not display a positive relationship between temperature and pressure. On the contrary, they show a negative relationship (Fig. 4). One possible explanation for this feature is that the fluid temperatures were not same as that of the host rocks. An alternate possibility is that the ratio of fluid pressure estimated from the post-mélange veins to lithostatic pressure is not constant. Fluid pressure could be intermediate between lithostatic pressure and hydrostatic pressure. We estimate a geothermal gradient of $22^{\circ} \mathrm{C} / \mathrm{km}$ from the age of the subducting plate (about $50 \mathrm{Ma}$ ) on the basis of the heat flow calculated from the equation of Parsons and Sclater (1977), and assuming a thermal conductivity of $3.0 \mathrm{Wm}^{-1}{ }^{\circ} \mathrm{C}^{-1}$. This value is in close correspondence with the geothermal gradient estimated from investigations on illite crystallinity and lattice b0 spacing from the northern part of the Cretaceous
Shimanto Belt in Kii Peninsula (Awan and Kimura, 1996). The bulk density of the strata within the Nankai accretionary prism from the seafloor to $1300 \mathrm{mbsf}$ shows as increase from 1.5 to $2.5 \mathrm{~g} / \mathrm{cm}^{3}$ (Taira et al., 1992). The bulk density below $1300 \mathrm{mbsf}$ is assumed to be $2.5 \mathrm{~g} / \mathrm{cm}^{3}$. On the basis of the density, the geothermal gradient lines for the lithostatic and hydrostatic pressures are represented in Fig. 4. Five out of six data on the P-T condition from the post-mélange veins fall between the two geothermal gradient lines. This result supports the latter assumption that the ratio of fluid to lithostatic pressure is not constant in each sample. In this study the highest value of pressure (highest methane density) in each sample has been taken into account for pressure computations (see section of fluid inclusions). Abnormal fluid pressure ( $90 \%$ of lithostatic pressure) is reported along the shallow part of decollement from ODP operation (Moore et $a l ., 1995)$. Because the post-mélange veins analyzed in this study are located along thrusts of duplex structure, we envisage that the fluid migrated along decollement. Therefore, it is possible that the pressure conditions of the fluids that formed the post-mélange veins were close to $90 \%$ of lithostatic pressure, although the abnormal fluid pressure is reported only at the shallow part of subduction zone. If the assumption that the fluid pressure estimated from the postmélange veins is equivalent to $90 \%$ of lithostatic pressure is valid, then most of the P-T conditions from the post-mélange veins represent higher temperature than that of host rocks as estimated from the geothermal gradient of slab age. It is thus indicated that fluids having higher temperatures than the host rocks migrate from deeper part along localized faults forming duplex structure. The hot fluid does not raise geothermal gradient because localized fluid does not disturb the vitrinite reflectance trend increasing from the north to the south (Underwood et al., 1989; Sakaguchi, 1996; Ohmori et al., 1997).

Temperature range of syn-mélange veins is from ca. 150 $( \pm 25)^{\circ} \mathrm{C}$ to ca. $220( \pm 30)^{\circ} \mathrm{C}$ (Hashimoto et al., submitted), which is similar to that of post-mélange vein reported in this study. If the thermal model of seismogenic region (ca. 150 to $350^{\circ} \mathrm{C}$ : Hyndman and Wang, 1993) is true, both mélange and duplex structure are formed in seismogenic region. Because cataclasites are distributed only along duplex faults, deformation mechanism of duplexing is cataclastic as described. On the other hands, deformation mechanism of mélange formation is mainly that of pressure solution (i.e., Hashimoto and Kimura, 1999; Onishi et al., 2001). These facts suggest that the cataclastic deformation by duplexing is developed at the same tectonic level where the pressure solution accompanying mélange formation occurred.

Acknowledgments. We are grateful to Atsushi Yasuda for useful discussions and permission to use the FT-IR analytical facilities. We also thank M. Toriumi, T. Urabe, and A. Taira for their critical comments and constructive discussions. The manuscript is much improved in English by M. Santosh. The critical and constructive reviews by Dr. K. Kano and W. T. Parry improved the paper significantly. This research was supported in part by a grant from the Japan Society for the Promotion of Science (09362).

\section{References}

Angus, S., B. Armstrong, and K. M. de Reuck, International Thermody- 
namic Tables of the Fluid State, v. 5, Methane, Chem. Data Ser., 16, 247 pp., Pergamon, New York, 1976.

Awan, M. A. and K. Kimura, Thermal structure and uplift of the Cretaceous Shimanto Belt, Kii Peninsula, Southwestern Japan: An illite crystallinity and illite b0 lattice spacing study, The Island Arc, 5, 69-88, 1996.

Burruss, R. C., Analysis of phase equilibria in C-O-H-S fluid inclusions, Mineral Association of Canada short course Handbook, vol. 6, pp. 138$156,1981$.

Hashimoto, Y. and G. Kimura, Underplating process from mélange formation to duplexing: Example from the Cretaceous Shimanto Belt, Kii Peninsula, southwest Japan, Tectonics, 18(1), 92-107, 1999.

Hashimoto, Y., M. Enjoji, A. Sakaguchi, and G. Kimura, In-situ PressureTemperature conditions of a tectonic mélange: Constraints from fluid inclusion analysis of syn-melange veins, Island arc, submitted.

Hyndman, R. D. and K. Wang, Thermal constraints on the zone of major thrust earthquake failure: the Cascadia subduction zone, J. Geophys. Res., 98, 2039-2060, 1993.

Kimura, G. and A. Mukai, Underplated units in an accretionary complex: Melange of the Shimanto Belt of eastern Shikoku, southwest Japan, Tectonics, 10, 31-50, 1991

Moore, J. C., G. F. Moore, G. R. Cochrane, and H. J. Tobin, Negativepolarity seismic reflections along faults of the Oregon accretionary prism indicators of overpressuring, J. Geophys. Res., 100, 12895-12906, 1995.

Murata, A., Duplex structures of the Uchinohae formation in the Shimanto Terrane, Kyushu, southwest Japan, J. Geol. Soc. Jpn., 97, 39-52, 1991.

Ohmori, K., A. Taira, H. Tokuyama, A. Sakaguchi, M. Okamura, and A. Aihara, Paleothermal structure of the Shimanto accretionary prism, Shikoku, Japan: Role of an out-of-sequence thrust, Geology, 25, 327330, 1997.

Onishi, T. C. and G. Kimura, Mélange fabrics and relative convergence in subduction zone, Tectonics, 14, 1273-1289, 1995.

Onishi, C. T., G. Kimura, Y. Hashimoto, K. Ikehara-Ohmori, and T.
Watanabe, Deformation history of tectonic melange and its relationship to the underplating process and relative plate motion: An example from the deeply buried Shimanto Belt, SW Japan, Tectonics, 20, 376-393, 2001.

Parsons, B. and J. G. Sclater, An analysis of the variation of ocean floor bathymetry and heat flow with age, J. Geophys. Res., 82, 803-827, 1977.

Roedder, E., Fluid inclusions, Reviews in Mineralogy, 12, Mineralogical Society of America, Washington D.C., 644 pp., 1984.

Sakaguchi, A., High paleogeothermal gradient with ridge subduction beneath the Cretaceous Shimanto accretionary prism, southwest Japan, Geology, 24, 795-798, 1996.

Sakaguchi, A. and E. Ikesawa, The cyclic mechanism of the seismogenic fault rock in ancient subduction zone, the Shimanto accretionary prism, southwest Japan, Eos Trans. $A G U, \mathbf{8 1}(48)$, Fall Meet. Suppl., Abstract T51A-02, 2000.

Silver, E. A., M. J. Ellis, N. A. Breen, and T. H. Shipley, Comments on the growth of accretionary wedges, Geology, 13, 6-9, 1985.

Taira, A., I. Hill, J. Firth, U. Berner, W. Bruckmann, T. Byrne, T. Chabernaud, A. Fisher, J. P. Foucher, T. Gamo, J. Gieskes, R. Hyndman, D. Karig, M. Kastner, Y. Kato, S. Lallemand, R. Lu, A. Maltaman, G. Moore, K. Moran, G. Olaffson, W. Owens, K. Pickering, F. Siena, E Taylor, M. Undersood, C. Wilkinson, M. Yamano, and J. Zhang, Sediment deformation and hydrogeology of the Nankai Trough accretionary prism: Synthesis of shipboard results of ODP Leg 131: Earth Planet. Sci. Lett., 109, 431-450, 1992.

Underwood, M. B., M. M. Laughland, T. J. Wiley, and D. G. Howell, Thermal maturity and organic geochemistry of the Kodiak Basin region, east-central Alaska, U.S. Geological Survey Open-File Report, 41, 89$353,1989$.

Y. Hashimoto (e-mail: hassy@cc.kochi-u.ac.jp), M. Enjoji, A. 